\title{
The organisation, role, facilities and responsibilities for civil defence in the northern region
}

This subject will be dealt with in the following three papers. Contributions by:-

(1) Regional Commissioner, Northern Region

(2) Civil Defence Officer, No.I Sub Region

(3) Civil Defence Officer, Tauranga Joint Civil Defence Org.

\section{MINISTRY OF DEFENCE}

\section{Background Information}

In 1935, the Emergency Precautions Committee of the New Zealand Committee of Imperial Defence, was set up and addressed itself to three main problems -

(1) Protection against air attack

(2) Anti-gas Defence

(3) Earthquake Precautions.

In 1937, this committee merged in the newly formed organisation of National Security.

In 1939, the Emergency Precautions Scheme was published. According to this, Local Authorities were given the responsibility of organising a local scheme with Government Departments affording cooperation and assistance. Thus we see the emergence of a fundamental principle, the active involvement of Local Government in what is now called Civil Defence.

The scheme in detail concerned itself primarily with measures for dealing with large-scale natural disasters. It was, however, recognised that such plans would also be applicable in the event of attack. It is interesting to note that the emphasis was on precautions against earthquakes, and the dangers of possible enemy action were

* Commodore (ret.), Regional Commissioner Ministry of Civil Defence, Auckland 
deliberately not stressed. One is tempted to ask, will history repeat itself?

During the war years, Central Government exerted most control when the threat of enemy action was greatest, even to the extent of introducing the principle of compulsion in E.P.S. duties. As the Japanese threat receded, Local Authorities regained the element of control which they had lost, and in 1944, the administration of E.P.S. reverted to the Department of Internal Affairs.

\section{Post-War Development}

Some Local Authorities kept their E.P.S. organisations alive after the war, but in the main they lapsed. Local Authorities could scarcely be expected to maintain an active interest in Emergency Precautions unless a lead was given by Central Government.

\section{Emergency Powers Act, 1953}

As a first approach to the problem, the Local Authority Emergency Powers Act of 1953 was passed. This Act empowered, but did not require, Local Authorities to prepare against threats, whether arising from war or natural disaster. The Act spoke of the functions of Local Authorities only and had little to say about the Civil Defence functions of Central Government. Although Local Authorities were empowered to unite for Civil Defence purposes, the Act provided no machinery for National or Regional planning or for its coordination with Local Government planning. The response of Local Authorities under this Act was only sporadic and there were doubts on relative responsibility between the Act of 1953 and the Public Safety Conservation Act of 1932, which gave Police special powers in emergency conditions.

\section{Establishment of Ministry of Civil Defence}

In 1958 the Government issued a White Paper, "Review of Defence" . This paper called for planning, preparations, training and public education for civil defence in war and stated that a Ministry of Civil Defence would be established.

The portfolio of Minister of Civil Defence was assumed by the Minister for Internal Affairs. The Secretary for Internal Affairs became the Director of Civil Defence and, to assist with the planning of measures, a number of National Planning Committees were set up to report to and advise the Minister. At this stage it was envisaged that all metropolitan areas and Boroughs with populations of 10,000 ore more would have Civil Defence organisations. Other Boroughs and Townships would be well advised to have them, and rural areas need only be concerned with reception arrangements and plans in respect of fallout. It was decided that the organisation would follow the United Kingdom model, adapted to meet the threat from natural disaster and take into account advice received from the Australian Civil Defence Authorities. 
In June 1960, as an essential and integral part of the planning of the Central Government effort, organisational arrangements were made to extend Central Government planning to the regional level. Three Regional Commissioners were appointed, one stationed in Auckland, one in Palmerston North and one in Christchurch. Their functions were to promote civil defence within their Regions and assist Local Authorities in the preparation of their Civil Defence Plans. At this stage, the legislation under which civil defence was being developed, was the Local Authorities' Emergency Powers Act passed in 1953. It soon became apparent that other legislation was needed.

\section{The Civil Defence Act of 1962}

By December 1962 the appropriate legislation had been prepared and the Civil Defence Act, 1962, was passed. This repealed the Local Authorities' Emergency Powers Act and amended the Public safety Conservation Act. It required that ALL Local Authorities should have a Civil Defence Plan approved by the Regional Commissioner. There was, however, no penal clause for non-compliance. It set out the functions and powers of Central Government and its officers, provided for the formal declaration of a State of Major Disaster, and defined the relationships between Central and Local Government, and between Local Authorities themselves, for the purposes of Civil Defence. It also set out the functions and powers of Local Authorities and the means of bringing these powers into effect by a Declaration of Major Disaster. It permitted Local Authorities to join together in the preparation of their civil defence measures. The provision of Part $V$ of the War Pensions Act 1954, was made applicable to persons injured during civil defence work. The establishment of a National Civil Defence Committee and Regional Civil Defence Committees was authorised.

\section{Appointment of Full-time Director}

By 1965, the work of the Directorate warranted the appointment of a full-time Director of Civil Defence, the then Director becoming Secretary for Civil Defence in addition to his appointment as secretary for Internal Affairs.

The Director chairs the National Civil Defence Committee which directs the work of the National planning Committees. A series of Government Plans has been issued dealing with Government and Departmental Action in National Emergency and Major Disaster, and the development of Civil Defence measures.

A National Civil Defence Operational Headquarters has been established in the basement of Broadcasting House in Wellington. This HQ will be transferred to the basement of the Beehive Building when it is completed. 


\section{Ministry of Civil Defence}

The Ministry of Civil Defence produces a series of training manuals for the guidance of Local Authority Civil Defence organisations. It pays for the training of Local Authority nominees who attend training courses at the Australian Civil Defence School at Macedon, Victoria, and those run by the Regional Commissioners within their Regions.

\section{Subsidies}

A subsidy scheme has been established, whereby Government reimburs $\epsilon$ Local Authorities on a 50-50 basis for expenditure on essential items of communications and training equipment. To encourage Local Authorities to employ a Civil Defence Officer to organise their civil defence measures, the salaries of these officers are likewise subsidised.

As a result of experience gained, the Act was amended in 1965. $' 67$ and '68. These amendments included the substitution of the term "Civil Defence Emergency" for "Major Disaster", and made it easier for a Local Authority or Combining Local Authorities to make a Declaration of a Local Civil Defence Emergency. The compensatory and protective clauses both for the individual and for the Local Authority, were improved. The 1968 amendment gave the Act some teeth in that it made it a statutory requirement that all Local Authorities MUST have an approved Civil Defence Plan by 31 December, 1969.

Because the threat of nuclear attack is at present considered remote, priority is now given to emergency measures in respect of natural disasters, with planning against wartime requirements taking second place.

\section{The Philosophy of Civil Defence}

Every community, large and small, must be prepared to look after itself in a civil defence emergency. Each community must also be prepared to look after a stricken neighbour. The responsibility has been delegated, and rightly so, to Local Government. The Local Authority, which provides most of a community's needs in normal times. should continue to do so when the community is disrupted. Control must remain in their hands when things go wrong just as it does in normal times. Who is better placed to meet the first critical period, with communications cut and road and rail links out of action? The only help available in the crucial first few hours is that to be found within the community itself. Outside help cannot be marshalled soon enough. This is the philosophy of Civil Defence.

The purpose is, very simply, to prevent and reduce loss of life and human distress in disaster, whether it is a local, regional, or even a national, emergency. There must be plans to carry out this purpose. Muddling through is never good enough and has never been good enough. There must be a simple organisation, spearheaded by Local Government resources, and capable of swift action. 
Thus Civil Defence is everybody's business. Not just Government's, or Local Authorities, or the various Societies, national, local and all sorts. It is above all the concern of every citizen, parent and householder. To this end, the Local Organisation is supported by the resources of the state.

\section{The Northern Civil Defence Region}

The Regional Commissioner Northern Region is responsible for the administration of the Act in his Region. This includes coordination of the planning of civil defence measures throughout the Northern half of the North Island. His Region comprises all that territory north of and inclusive of opotiki county, Taupo Country and Waitomo County. Figure 1 shows this territory divided into its constituent Local Authority Subregions and Areas. The No.I Subregion is fully operational and is the subject of the second paper in this series. The other Subregions based on Whangarei. Hamilton and Rotorua are not so well developed and exist at present for coordinating and communication purposes only. The Area organisations are all in existence and the majority of them have plans approved by the Regional Commissioner. In nearly all cases, the Area Organisations are Joint ones, i.e. they comprise a number of Local Authorities who have combined and produced a joint plan. such arrangement has much to recommend it in that it ensures cooperation, pooling of resources and mutual support between adjacent authorities. both in the planning and operational stages.

The Regional Headquarters, both for administration and operations, is situated in Auckland. The administrative staff is small, consisting only of the Regional Commissioner, Assistant Regional Commissioner, Regional Training Officer and a Personal Assistant.

The Regional Commissioner chairs a Regional Civil Defence Committee, the members of which are senior representatives of Departments of State, whose Departmental Heads sit on the National Civil Defence Committee in Wellington. The function of this Committee is to assist the Regional Commissioner to plan the use of coordinate and use for the purposes of civil defence, personnel, material and services available within the Region.

The Regional Operational Headquarters is permanently established. It has an Operations Room, a Conference Room and an Information Room, and is fitted with special communications arrangements. The latter include direct telephone lines to Services Headquarters and major Departments and No.I Subregional Control. A teleprinter and radio circuits give access to Regional Commissioners at Palmerston North and Christchurch and to National Civil Defence Headquarters. The Railway telephone network is available for civil defence purposes. The Headquarters is manned during an emergency by a team provided by the Armed Services, the Post office and the Internal Affairs Department, with a liaison staff from the major Government Departments concerned with civil defence. There is a Transport Sub committee of the Regional Committee which includes representatives of the major oil companies, Armed Service and Government Transport units, under the Chairmanship 
of the Regional Railways Traffic Manager. The oil Companies have their own Industrial Civil Defence Organisation based on the Civil Defence Regional and Subregional Organisation.

The principal functions of the Regional Commissioner during Civil Defence operations are:-

1. To coordinate the use of, and use for the purposes of the Act, personnel, material and services available in Departments of state, other Government agencies, statutory corporations, public bodies and other organisations.

2. To provide, direct and coordinate personnel, material and services available and at his disposal for the purpose of aiding any local authority or uniting local authorities. that have requested aid from him.

3. To arrange and coordinate mutual relief and assistance between local authorities.

4. To disseminate to local authorities and to the public, information and advice.

\section{Communications}

Communications are a vital factor in the discharge of these functions. The post office telecommunications system, backed up by Railways telephone system, provides the primary means. As this system is liable to disruption during some forms of natural disaster. provision is made for alternative arrangements. The principal alternatives are the use of radio and message carrying agencies. Full use will be made of the National Broadcasting system. proposals to extend the system of radio coverage are being examined. Arrangements are made to make use of the many Departmentally controlled communication systems. These are shown in Figure 2 .

Priorities have been laid down for the passing of Civil Defence messages over Post office and Civil Defence communications systems and for the restoration of damaged post office circuits.

\section{Early Warning System}

An Early Warning System has been developed which provides for the rapid passing of a message from Civil Defence Headquarters at Wellington to all Local Civil Defence Organisations in the country. Alternatively it enables a Regional Commissioner to pass a warning message to all Civil Defence Organisations within his Region. The originator passes the message via Post Office tolls to Police District Headquarters, from which it is transmitted to Police stations for despatch to Civil Defence organisations. Snap tests are carried out at intervals, resulting in an average delivery time of 18 minutes to Local Civil Defence organisations. Warning to the public is the responsibility of Local Civil Defence and is given by various means. 
The national warning signal, more than five long blasts of five seconds duration at five second intervals by siren, factory whistle, ships' sirens and similar devices, warns the public to tune in to the National Broadcasting network for advice and instructions concerning the threat. All telephone directories print this instruction on the back page, together with other civil defence advice. Some four cities have installed additional sirens, which serve to augment the coverage obtained by the Fire Sirens.

\section{The Region in Action}

Civil Defence action at Regional level will vary according to the nature, extent and magnitude of the Civil Defence Emergency. Given early warning, immediate steps will be taken to activate Regional HQ, establish communication with threatened areas, and alert Civil Defence Organisations. These Areas will be encouraged to declare a State of Civil Defence Emergency. The link between Region and those on the spot is illustrated in Figure 3.

The major threat, earthquake, cannot be forecast. It will come suddenly, without warning, and must be met with what despatch the Local Organisation is capable of, and with whatever resources are present and available. How the Civil Defence of a community is planned and arranged to meet such a threat, will be dealt with in the third of these papers.

The function of Region is to bring support and assistance to the controller in the devastated area. It may be necessary to extend the State of Civil Defence Emergency beyond the areas affected, to facilitate control measures and increased support for the operation. A major problem of disaster is that of control of the people from outside a stricken area, the anxious, the curious, the would-be helpers, the exploiters, who for a variety of reasons converge upon the scene, blocking the roads and streets, crowding the hospitals and Welfare Centres, jamming the telephones, and generally adding to the chaos and confusion. It is in this way, as well as with the provision of support manpower, vehicles, supplies and communications - that Region can aid a stricken area. 


\section{CIVIL DEFENCE-NORTHERN REGION}

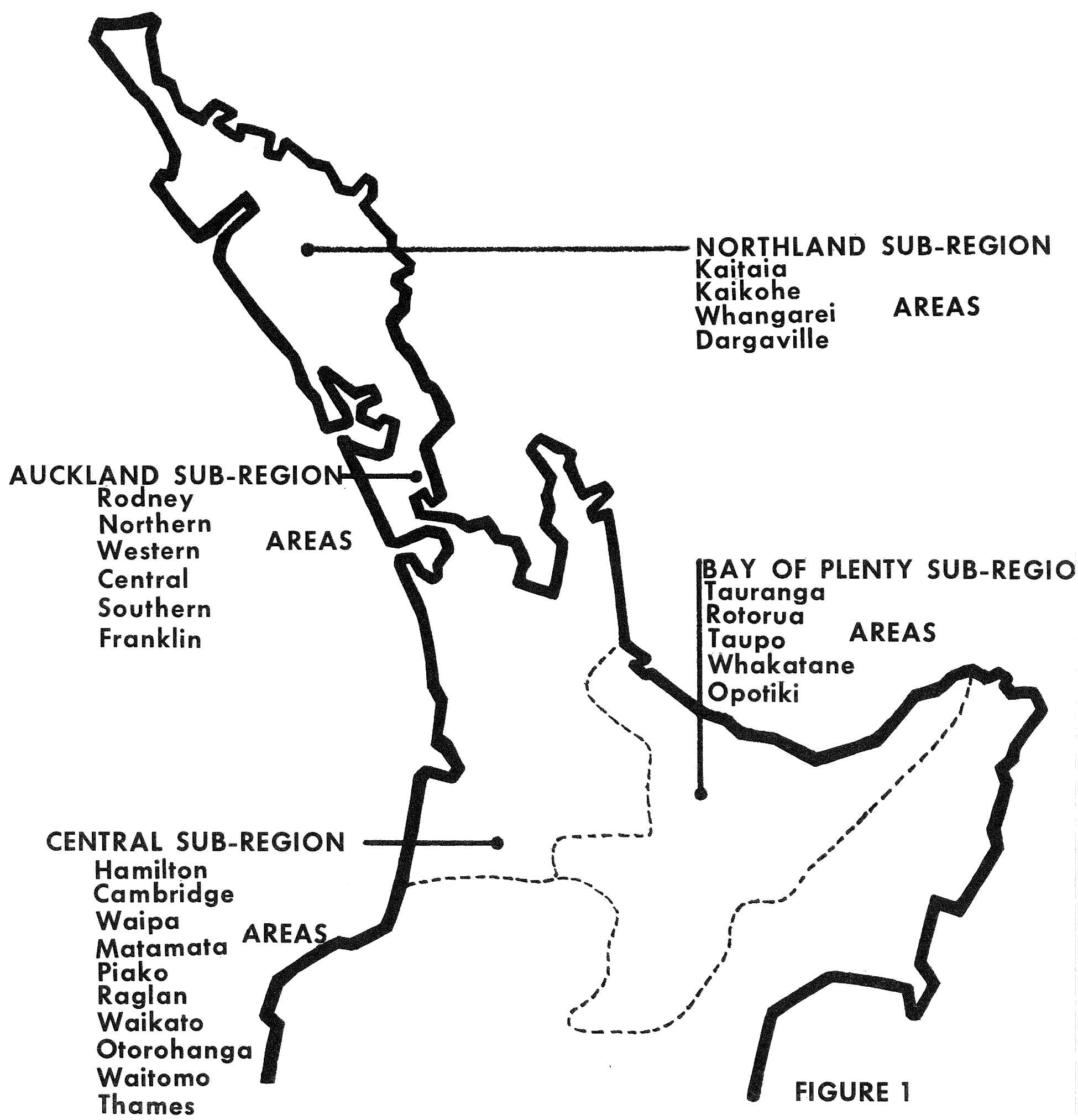




\section{"BACK UP" COMMUNICATIONS}

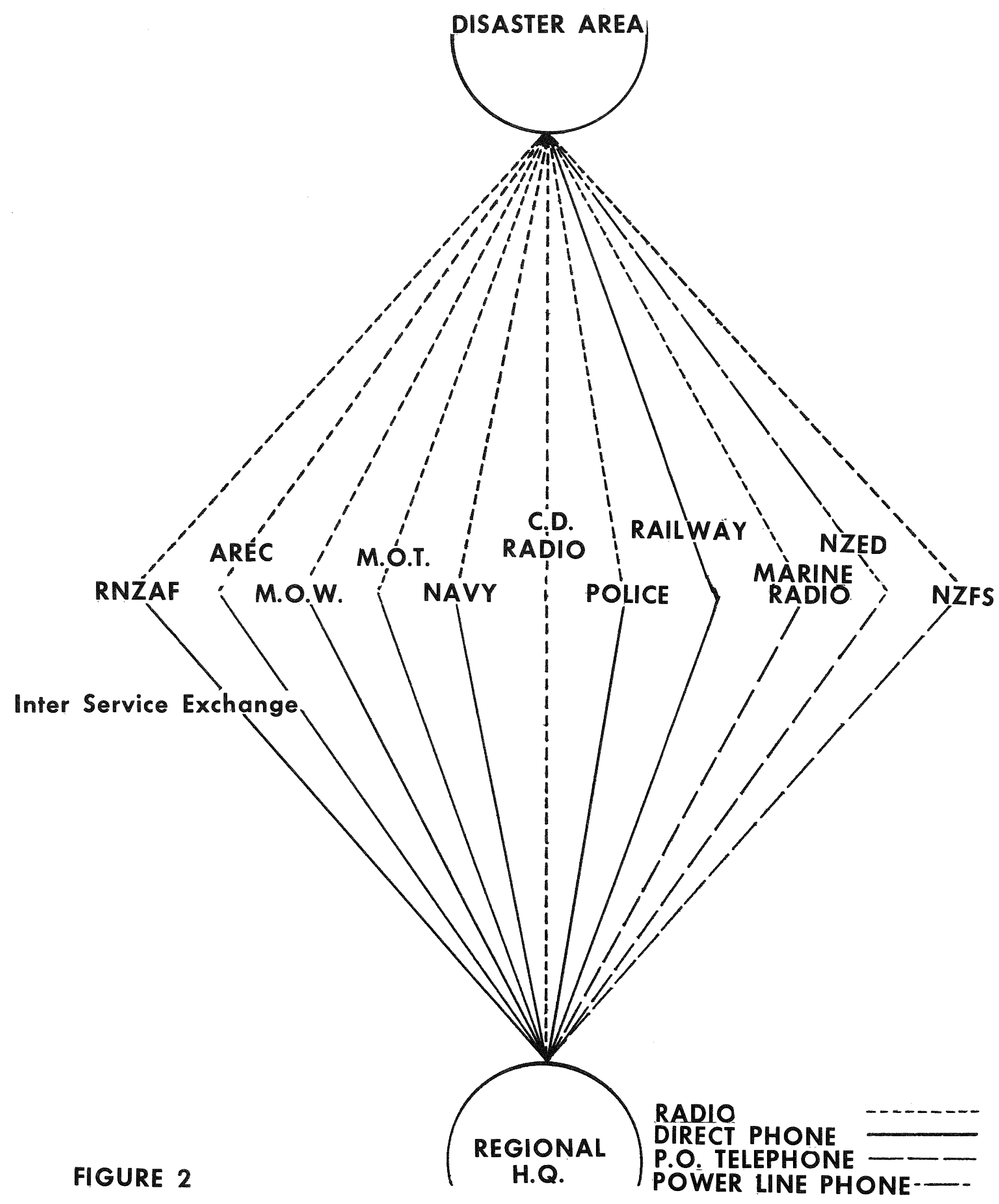




\section{CIVIL DEFENCE}

CHAIN OF CONTROL \& COMMUNICATION

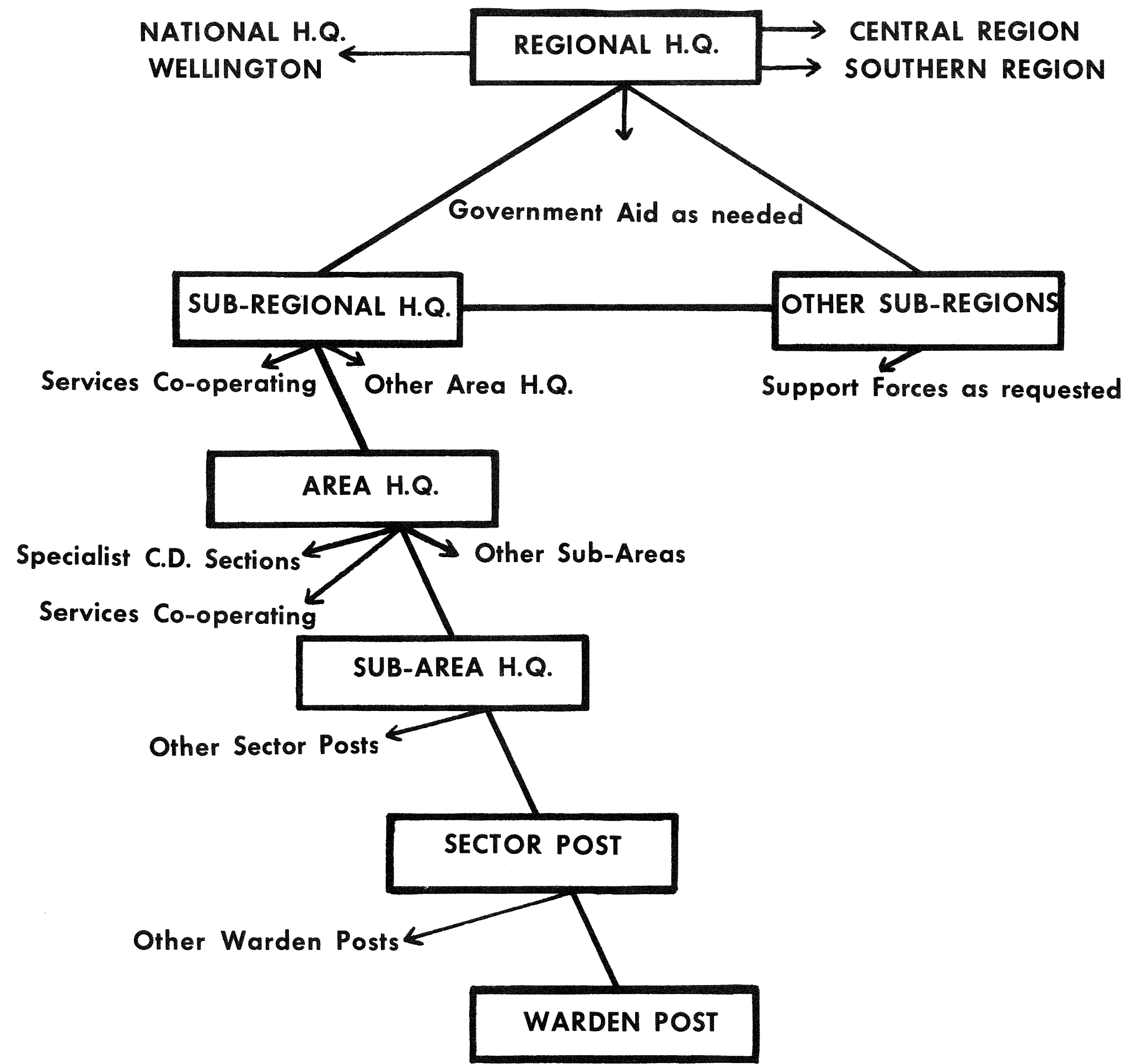

